\title{
Implementasi Sistem Pakar Dalam Mendiagnosa Penyakit Kepiting Menggunakan Metode Certainty Factor Berbasis Web
}

\author{
Implementation of an Expert System in Diagnosing Crab Disease Using the Web-Based \\ Certainty Factor Method
}

Rio Bayu Sentosa* ${ }^{* 1}$, Yeviki Maisyah Putra ${ }^{2}$

${ }^{1,2}$ Fakultas Ilmu Komputer, Universitas Putra Indonesia

E-mail: ${ }^{1}$ riobayusentosa@ upiyptk.ac.id, ${ }^{2}$ yeviki.maisyahputra@ upiyptk.ac.id,

\begin{abstract}
Abstrak
Sistem pakar merupakan cabang dari kecerdasan buatan dan juga merupakan bidang ilmu komputer yang muncul seiring perkembangan ilmu komputer saat ini. Sistem ini bekerja untuk mengadopsi pengentahuan manusia ke komputer yang menggabungkan dasar pengetahuan (knowledge base) dengan sistem inferensi untuk mengantikan fungsi seorang pakar dalam menyelesaikan suatu masalah. Pada penelitian ini jenis kepiting yang akan di diagnosa adalah kepiting soka, Kepiting soka (soft cell crabs) merupakan kepiting pada fase ganti kulit (molting) atau kepiting cangkang lunak. Permasalahan yang timbul terhadap kepiting soka dalam proses pemeliharaan dikarenakan faktor penyakit, Munculnya gangguan penyakit pada kepiting merupakan resiko yang harus selalu diantisipasi. Untuk mengatasi masalah tersebut, maka di terapkanlah suatu sistem pakar untuk mendiagnosa penyakit pada kepiting soka menggunakan metode certainty factor dimana dari sistem ini masyarakat dapat mengetahui tentang cara menangani masalah penyakit pada kepiting soka dan memberikan kemudahan bagi masyarakat dalam proses implementasinya.
\end{abstract}

Kata kunci: Sistem Pakar, Certainty Factor, Kepiting Soka

\begin{abstract}
Expert systems are a branch of artificial intelligence and are also a field of computer science that has emerged with the development of computer science today. This system works to adopt human knowledge to a computer that combines a knowledge base with an inference system to replace the function of an expert in solving a problem. In this study the type of crab that will be diagnosed is soft-cell crabs, soft cell crabs are crabs in the molting phase or soft shell crabs. Problems that arise with soka crabs in the maintenance process are due to disease factors. The emergence of disease disorders in crabs is a risk that must always be anticipated. To overcome this problem, an expert system is applied to diagnose diseases in soft-shelled crabs using the certainty factor method where from this system the public can find out about how to deal with disease problems in soft-shelled crabs and provide convenience for the community in the implementation process.
\end{abstract}

Keywords: Expert System, Certainty Factor, Crab Soka

\section{PENDAHULUAN}

Sistem pakar merupakan salah satu bagian dari kecerdasan buatan yang akhir-akhir ini mengalami perkembangan yang sangat pesat. Sistem pakar merupakan cabang dari AI (Artificial Inteligent) yang membuat ekstensi untuk spesialisasi pengetahuan guna memecahkan suatu permasalahan pada Human Expert[1] Sistem ini dirancang untuk menirukan keahlian seorang pakar dalam menjawab pertanyaan dan menyelesaikan suatu permasalahan baik di bidang

(C) 2022 The Author(s). Published by AIRA. This is an open access article under the CC BY-SA license 
kesehatan atau kedokteran, bisnis, ekonomi dan sebagainya. Sistem pakar merupakan program komputer yang mampu menyimpan pengetahuan dan kaidah seorang pakar yang khusus. Sistem pakar sangat membantu untuk pengambilan keputusan, dimana sistem pakar ini dapat mengumpulkan dan menyimpan pengetahuan dari seseorang atau beberapa orang pakar dalam suatu basis pengetahuan (knowledge base) dan menggunakan sistem penalaran yang menyerupai seorang pakar dalam memecahkan masalah. Jadi, sistem pakar ini dapat memecahkan suatu masalah tertentu karena sudah menyimpan pengetahuan secara keseluruhan[2].

Kepiting soka (soft cell crabs) merupakan kepiting pada fase ganti kulit (molting) atau kepiting cangkang lunak. Kepiting pada fase ini dapat dimanfaatkan secara utuh sehingga hal ini menjadi keunggulan kepiting soka, Habitat kepiting soka adalah daerah hutan mangrove, sehingga budidaya di daerah ini berkembang baik, ketersediaan bibit kepiting dan ikan rucah sebagai pakan melimpah. Selain itu, permintaan kepiting soka yang terus meningkat menjamin harga pasar yang menarik bagi nelayan[3].

Faktor kepastian (certainty factor) diusulkan oleh Shortliffe dan Buchanan pada 1975 untuk mengakomadasikan ketidakpastian pemikiran (inexact reasoning) seorang pakar. Seorang pakar, (misalnya dokter) sering kali menganalisis informasi yang ada dengan ungkapan seperti misalnya: mungkin, kemungkinan, besar, hampir pasti. Untuk mengakomodasi hal ini dengan menggunakan certainty factor (CF) guna menggambarkan tingkat keyakinan pakar terhadap masalah yang dihadapi. Secara umum, rule direpresentasikan dalam bentuk sebagai berikut[4].

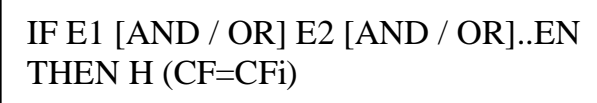

Dimana:

E1...En : fakta-fakta (evidence) yang ada : hipotesa atau konklusi yang dihasilkan

$\mathrm{H} \quad$ : hipotesa atau konklusi yang dihasilkan

$\mathrm{CF} \quad$ : tingkat keyakinan (certainty factor) terjadinya hipotesa akibat adanya faktafakta SPK

Teori Certainty Factor adalah Faktor kepastian (certainty factor) menyatakan kepercayaan dalam sebuah kejadian (fakta atau hipotesa) berdasar bukti atau penilaian pakar. Certainty factor menggunakan suatu nilai untuk mengasumsikan derajat keyakinan seorang pakar terhadap suatu data. Secara umum Teori Certainty Factor ditulis dalam suatu interval : Certainty factor menggunakan suatu nilai untuk mengasumsikan derajat keyakinan seorang pakar terhadap suatu data[5]. Penerapan metode CF pada sistem pakar memerlukan beberapa rule berupa variabel (gejala dengan simbol G) dan nilai bobot yang diberikan oleh pakar. Data sampel penyakit pasien diperoleh dari data rekam medis pasien penyakit THT oleh dr. M. Agus Sugicharto Sp.THT periode bulan Februari 2018. Nilai bobot dibutuhkan untuk setiap gejala pada setiap penyakit. Pakar memberikan skala nilai bobot untuk tiap gejala antara $0,2-1,0$. Rule CF yang berisi gejala dan nilai bobot dari pakar untuk setiap penyakit[6]

\section{A. Tahapan Penelitian}

\section{METODE PENELITIAN}

Penelitian merupakan kegiatan yang dilakukan secara terencana, teratur, dan sistematis untuk mencapai tujuan tertentu. Tahapan penelitian ini juga merupakan pengembangan dari kerangka penelitian, yang terbagi menjadi beberapa sub menu bagian[7]. Tahapan penelitian yang dilakukan dapat dilihat pada gambar berikut. 


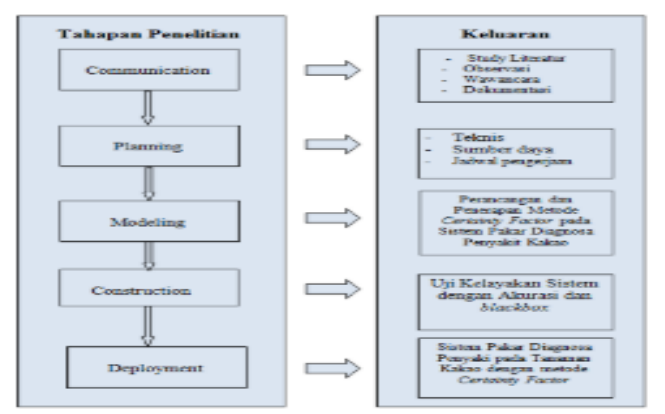

Gambar 1. Tahapan Penelitian

Metode Certainty Factor (CF) adalah teori yang digunakan untuk mengakomodasi ketidakpastian pemikiran (inexact reasoning) seorang pakar[8].

B. Analisa Sistem

Tahapan analisa sistem dilakukan setelah tahapan perencanaan sistem dan sebelum tahapan desain sistem. Tahapan analisa sistem merupakan tahapan yang kritis dan sangat penting karena kesalahan ditahap ini akan menyebabkan kesalahan ditahap selanjutnya.[2]. Tahap Analisa data dan kebutuhan sistem, dilakukan setelah tahapan pengumpulan data selesai dilakukan[9]

C. Metode Pengumpulan Data

Metode pengumpulan data yang digunakan dalam penelitian ini adalah metode deskriptif. Adapun teknik pengumpulan data dilakukan dengan cara sebagai berikut:

- Analisa Masalah

Masalah dilakukan dalam pengamatan pada pemula yang baru melalakukan budidaya kepiting asoka.

- $\quad$ Studi Pustaka

Pengumpulan data dengan menggunakan atau mengumpulkan sumber-sumber tertulis, dengan cara membaca, mempelajari dan mencatat hal-hal penting yang berhubungan dengan masalah yang sedang dibahas guna memperoleh gambaran secara teoritis.

D. Rule Diagnose Penyakit Kepiting Soka

Berikut adalah deskripsi aturan pada aplikasi diagnosa penyakit kepiting asoka menggunakan metode certainty factor:

1. Gejala

Tabel 1. Gejala

\begin{tabular}{|l|l|l|}
\hline Kode & Gejala & Nilai \\
\hline G01 & terlihat terang dalam keadaan gelap (malam hari). & 0.5 \\
\hline G02 & Perubahan suhu & 0.7 \\
\hline G03 & terjadi luka-luka di pinggiran kulit pada ruas perut & 0.6 \\
\hline G04 & timbulnya bercak-bercak hitam pada luka & 0.8 \\
\hline G05 & borok pada kulit & 0.6 \\
\hline G06 & luka kemerahan pada mulut & 0.3 \\
\hline G07 & perut membengkak & 0.4 \\
\hline G08 & penurunan kualitas air & 0.7 \\
\hline G09 & perubahan warna cangkang keras & 0.5 \\
\hline G10 & gerakan kepiting melemah & 0.6 \\
\hline
\end{tabular}

2. Penyakit

Tabel 2. Penyakit

(C) 2022 The Author(s). Published by AIRA. This is an open access article under the CC BY-SA license (http://creativecommons.org/licenses/by-sa/4.0/) 


\begin{tabular}{|l|l|}
\hline Kode & Penyakit \\
\hline P01 & Vibrio spp \\
\hline P02 & Aeromonas spp \\
\hline P03 & Salmonella spp \\
\hline
\end{tabular}

2. Aturan

\begin{tabular}{|l|l|l|}
\hline Kode & Penyakit & Kode Gejala \\
\hline P01 & Vibrio $s p p$ & G01, G02, G03, G04 \\
\hline P02 & Aeromonas spp & G05, G06, G07 \\
\hline P03 & Salmonella $s p p$ & G08, G09, G10 \\
\hline
\end{tabular}
manual :

Berikut adalah hasil diagnosa Aeromonas spp dengan menggunakan perhitungan secara

1. Aeromonas spp

CFgejala G20 $=$ CFuser $(0.8) * \mathrm{CF}(0.6)$ $=0.48$

CFgejala G21 $=$ CFuser $(0.8) * \mathrm{CF}(0.3)$ $=0.24$

CFgejala G22 $=$ CFuser $(0.8) * \mathrm{CF}(0.4)$ $=0.32$

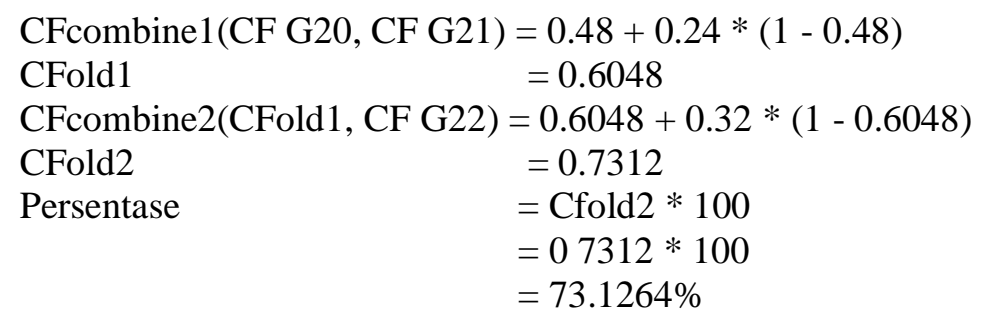

Dari perhitungan secara manual di atas, didapatkan nilai faktor kepastian dari masukan gejala yang mengarah ke Aeromonas spp adalah $73.1264 \%$.

\section{HASIL DAN PEMBAHASAN}

Dalam perancangan aplikasi diagnosa penyakit kepiting asoka ini, penulis menggunakan program aplikasi yang berbasis website dengan PHP sebagai bahasa pemrogramannya. Didalam aplikasi tersebut, pengguna hanya tinggal menjawab pertanyaan yang diberikan dengan memilih jawaban yang telah disediakan. Sehingga didapat hasil dari jawaban yang telah dijawab pengguna sebelumnya dan memberikan hasil diagnosa berupa persentase dari jawaban yang dipilih. Adapun alasan diatas nantinya diharapkan bisa lebih membantu dalam proses mencari penyakit yang menyerang kepiting asoka tersebut dengan menggunakan bantuan aplikasi berbasis website yang telah dirancang ini.

1. Tampilan Aplikasi Diagnosa Penyakit Kepiting Soka

Tampilan aplikasi diagnosa penyakit kepiting asoka ini terdiri dari tampilan pengertian, diagnosa dan tentang. Menu utama berisi menu - menu aplikasi yaitu pengertian kepiting, diagnosa dan tentang

- Halaman Utama

Tampilan menu utama terdiri dari pengertian kepiting asoka, diagnosa dan tentang. 


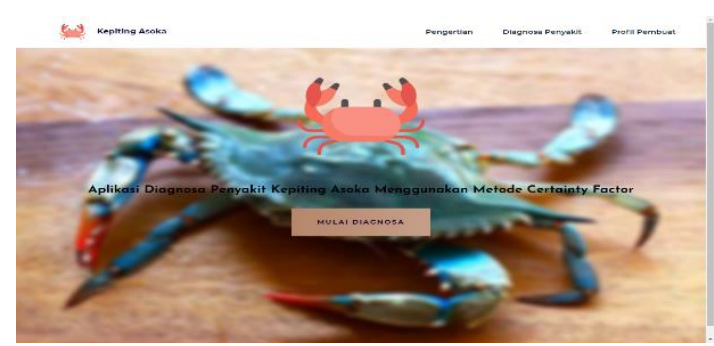

Gambar 2. Halaman Utama

- Tampilan Menu Pegertian

Tampilan pengertian adalah menu yang dapat melihat pengertian dari kepiting asoka tersebut.

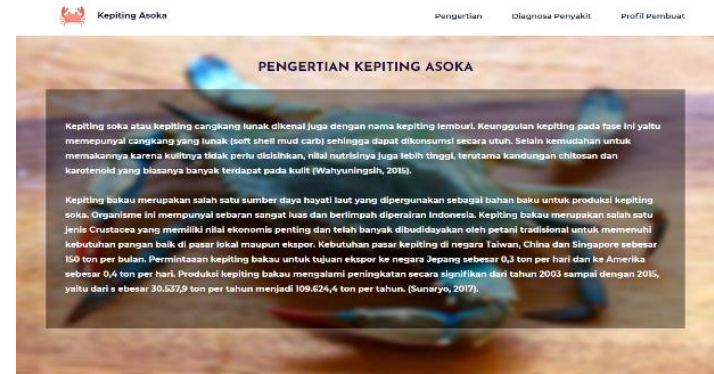

Gambar 3. Menu Pengertian

- Tampilan Diagnosa

Tampilan diagnosa berfungsi untuk melakukan diagnosa penyakit yang menyerang kepiting asoka.

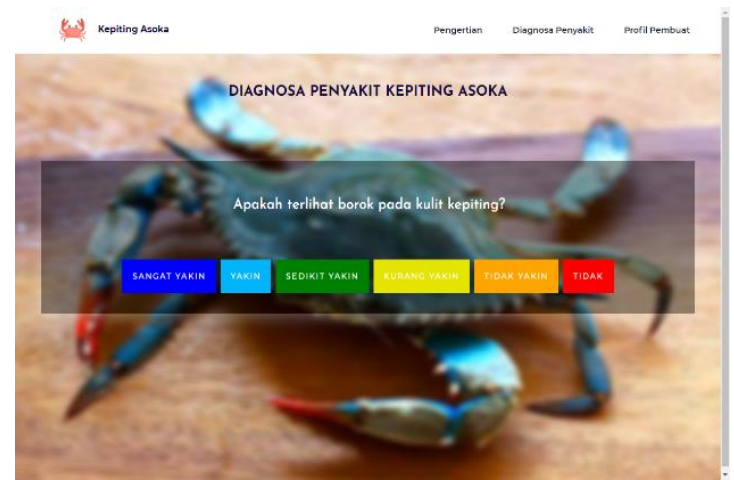

Gambar 4. Tampilan Diagnosa

- Tampilan Hasil

Tampilan hasil merupakan menu yang akan tampil apabila pengguna telah selesai menjawab pertanyaan yang diberikan.

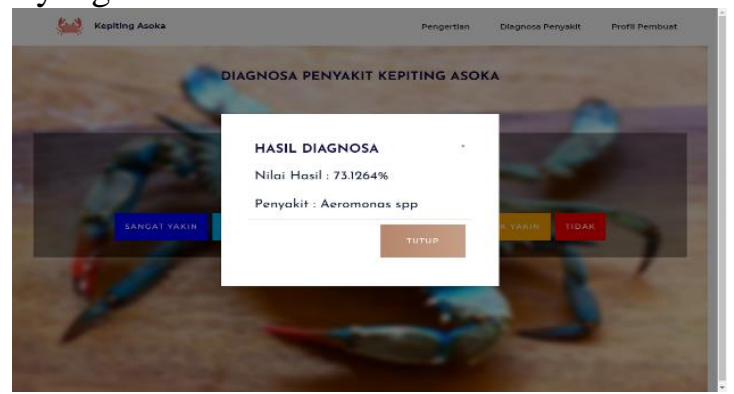

(C) 2022 The Author(s). Published by AIRA. This is an open access article under the CC BY-SA license 


\section{Gambar 5. Hasil Diagnosa}

2. Pengujian Aplikasi Dengan Blackbox

Sebuah program harus bebas dari kesalahan-kesalahan atau error. Oleh karena itu, program harus diuji coba terlebih dahulu untuk menemukan kesalahan-kesalahan yang mungkin terjadi, pengujian ini menggunakan metode pengujian black box. Pengujian black box berfokus persyaratan fungsional perangkat lunak. Pengujian ini berusaha menemukan kesalahan antara lain:

1) Fungsi-fungsi yang tidak benar atau hilang

2) Kesalahan interface

3) Kesalahan dalam struktur data

4) Kesalahan kinerja

Rencana pengujian yang akan dilakukan dengan menguji sistem secara blackbox. Rencana pengujian selanjutnya terlihat pada table dibawah ini :

Tabel 4. Rencana Pengujian

\section{Menu Yang Diuji \\ Detail Pengujian}

Jenis Uji
Diagnosa penyakit
Menjawab pertanyaan
Blackbox

- Kasus Dan Pengujian Dengan BlackBox

Berdasarkan rencana pengujian yang telah disusun, maka dapat dilakukan pengujian sebagai berikut :

1) Pengujian Diagnosa Penyakit

Tabel 5. Pengujian Diagnosa Penyakit

\begin{tabular}{|l|l|l|l|}
\hline \multicolumn{4}{|c|}{ Kasus dan hasil uji (data normal) } \\
\hline Data masukan & Yang diharapkan & Pengamatan & Kesimpulan \\
\hline Diagnosa Penyakit & $\begin{array}{l}\text { Menampilkan hasil } \\
\text { dari jawaban } \\
\text { pengguna }\end{array}$ & $\begin{array}{l}\text { Menjawab } \\
\text { pertanyaan }\end{array}$ & Diterima \\
\hline \multicolumn{3}{|c|}{ Kasus dan hasil uji (data tidak normal) } \\
\hline Data masukan & Yang diharapkan & Pengamatan & Kesimpulan \\
\hline Diagnosa Penyakit & $\begin{array}{l}\text { Pengguna tidak } \\
\text { menjawab } \\
\text { pertanyaan }\end{array}$ & $\begin{array}{l}\text { Hasil tidak ada } \\
\text { karena pengguna } \\
\text { hanya menjawab } \\
\text { tidak pada sistem }\end{array}$ & Diterima \\
\hline
\end{tabular}

Hasil pengujian dari pengujian blackbox yang telah dilakukan, menunjukkan bahwa aplikasi yang dibangun sudah memenuhi persyaratan fungsional. Akan tetapi, pada prosesnya masih memungkinkan untuk terjadi kesalahan. Secara fungsional sistem yang telah dibangun sudah dapat menghasilkan keluaran yang diharapkan.

\section{KESIMPULAN DAN SARAN}

A. Kesimpulan

Berdasarkan hasil pembuatan aplikasi diagnosa penyakit kepiting soka, maka didapat beberapa kesimpulan seperti berikut:

1) Aplikasi diagnosa penyakit kepiting asoka ini dapat lebih membantu bagi masyarakat yang baru memulai budidaya kepiting asoka dengan mengetahui penyakit kepiting asoka dengan mudah menggunakan aplikasi berbasis website. 
2) Aplikasi yang dibangun menggunakan metode certainty factor dalam melakukan kalkukasi perhitungan dari jawaban pengguna sehingga dapat memberikan hasil persentase.

B. Saran

Berikut adalah saran dari penulis agar aplikasi diagnosa penyakit kepiting soka ini dapat bermanfaat dan dikembangkan menjadi lebih baik lagi:

1) Sistem yang dibangun penulis hanya dapat dijalankan menggunakan media browser internet dan harus online. Kedepannya diperlukan pengembangan aplikasi offline agar dapat dijalankan apabila tidak tersedia koneksi internet.

2) Untuk saat ini sistem yang dibangun ini hanya dapat melakukan diagnosa penyakit pada kepiting asoka. Untuk kedepannya perlu diperbaharui dengan menyisipkan menu penambahan seperti jual beli kepiting asoka pada website.

\section{DAFTAR PUSTAKA}

[1] H. Haryadi and Y. Yulia, "Sistem Pakar Untuk Mendeteksi Kerusakan Pada Diesel Pump Dengan Metode Forward Chaining Berbasis Web," Innov. Res. Informatics, vol. 3, no. 1, pp. 164-170, 2021, doi: 10.37058/innovatics.v3i1.2831.

[2] Yuswandi and Dwi Yuli Prasetyo, "Sistem Pakar Diagnosa Penyakit Kepiting Bakau Menggunakan Metode Forward Chaining," J. Perangkat Lunak, vol. 1, no. 1, pp. 22-32, 2019, doi: 10.32520/jupel.v1i1.781.

[3] I. Suswanto and A. M. Sirodjul Munir, "Budidaya Kepiting Soka dengan Metoda Sangkar Massal," J. Pengabdi, vol. 1, no. 1, p. 7, 2018, doi: 10.26418/jplp2km.v1i1.25467.

[4] N. A. Hasibuan, H. Sunandar, S. Alas, and S. Suginam, "Sistem Pakar Mendiagnosa Penyakit Kaki Gajah Menggunakan Metode Certainty Factor," Jurasik (Jurnal Ris. Sist. Inf. dan Tek. Inform., vol. 2, no. 1, p. 29, 2017, doi: 10.30645/jurasik.v2i1.16.

[5] S. R. Ginting, N. S. W., \& Anita, "Kedelai Menggunakan Metode Certainty Factor," J. KomTekInfo, vol. 5, no. 1, pp. 36-41, 2018.

[6] K. E. Setyaputri, A. Fadlil, and S. Sunardi, "Analisis Metode Certainty Factor pada Sistem Pakar Diagnosa Penyakit THT,” J. Tek. Elektro, vol. 10, no. 1, pp. 30-35, 2018, doi: 10.15294/jte.v10i1.14031.

[7] S. Alim, P. P. Lestari, and R. Rusliyawati, "Sistem Pakar Diagnosa Penyakit Tanaman Kakao Menggunakan Metode Certainty Factor Pada Kelompok Tani Pt Olam Indonesia (Cocoa) Cabang Lampung," J. Data Min. dan Sist. Inf., vol. 1, no. 1, p. 26, 2020, doi: 10.33365/jdmsi.v1i1.798.

[8] R. Agusli, Sutarman, and Suhendri, "Sistem Pakar Identifikasi Tipe Kepribadian Karyawan Menggunakan Metode Certainty Factor," J. Ilm. Tek. Inf., vol. 7, no. 1, p. 22, 2017, [Online].

Available: https://stmikglobal.ac.id/journal/index.php/sisfotek/article/view/127/124.

[9] I. H. Santi and B. Andari, "Sistem Pakar Untuk Mengidentifikasi Jenis Kulit Wajah dengan Metode Certainty Factor," INTENSIF J. Ilm. Penelit. dan Penerapan Teknol. Sist. Inf., vol. 3, no. 2, p. 159, 2019, doi: 10.29407/intensif.v3i2.12792. 